\title{
Possibilities of the observation of chemical reactions during the preparation of intermetallics by reactive sintering
}

Pavel Novák, Alena Michalcová, Ivo Marek, Milena Voděrová, Dalibor Vojtěch

Department of Metals and Corrosion Engineering, Institute of Chemical Technology, Prague

During reactive sintering production of intermetallic compounds, the thermally-activated reactions usually proceed very rapidly. Therefore the description of the reaction mechanisms is a challenge for current scientists. This work presents four approaches, how to succeed in this task. Thermal analysis, reaction front quenching method, in situ diffraction analysis and process modelling are described.

Keywords: reactive sintering, powder metallurgy, microscopy, phase analysis, thermal analysis

\section{Acknowledgement}

This research was financially supported by Czech Science Foundation, project No. P108/12/G043.

\section{References}

[1] T.B. MASSALSKI, Binary Alloy Phase Diagrams, ASM Int., Materials Park, 1990.

[2] M.H. CHEN, L. GAO, J.H. ZHOU, M. WANG, Application of reaction sintering to the manufacturing of a spacecraft combustion chamber of SiC ceramics, Journal of Materials Processing Technology, 192 (2002) 408411.

[3] L. ZHAN, P. SHEN, Q. JIANG, The mechanism of combustion synthesis of (TiCxNy-TiB2)/Ni from a Ni-Ti-CBN system, Powder Technology, 205 (2011) 52-60.

[4] P. NOVÁK, V. KNOTEK, J. ŠERÁK, A. MICHALCOVÁ, D. VOJTĚCH, Synthesis of Fe-Al-Si intermediary phases by reactive sintering, Powder Metallurgy, 54 (2009) 167-171.

[5] E. POCHEĆ, S. JÓŹWIAK, K. KARCZEWSKI, Z. BOJAR, Fe-Al phase formation around SHS reactions under isothermal conditions, Journal of Alloys and Compounds, 509 (2011) 1124-1128.

[6] P. NOVÁK, A. MICHALCOVÁ, J. ŠERÁK, D. VOJTĚCH, T. FABIÁN, S. RANDÁKOVÁ, F. PRŮŠA, V. KNOTEK, M. NOVÁK, Preparation of Ti-Al-Si alloys by reactive sintering, Journal of Alloys and Compounds, 470 (2009) 123-126.

[7] P. NOVÁK, A. MICHALCOVÁ, M. VODĚROVÁ, M. ŠíMA, J. ŠERÁK, D. VOJTĚCH, K. WIENEROVÁ, Effect of reactive sintering conditions on microstructure of Fe-Al-Si alloys, Journal of Alloys and Compounds, 493 (2010) 81-86.

[8] S. JÓŹWIAK, K. KARCZEWSKI, Z. BOJAR, Kinetics of reactions in FeAl synthesis studied by the DTA technique and JMA model, Intermetallics, 18 (2010) 1332-1337.

[9] P. NOVÁK, A. MICHALCOVÁ, I. MAREK, M. MUDROVÁ, K. SAKSL, J. BEDNARČÍK, P. ZIKMUND, D. VOJTĚCH, On the formation of intermetallics in Fe-Al system - an in situ XRD study, Intermetallics, accepted (2012).

[10] C.L. YEH, C.C. HSU, An experimental study on Ti5Si3 formation by combustion synthesis in self-propagating mode, Journal of Alloys and Compounds, 395 (2005) 53-58.

[11] F. CHARLOT, F. BERNARD, E. GAFFET, D. KLEIN, J.C. NIEPCE, In situ time-resolved diffraction coupled with a thermal I.R. camera to study mechanically activated SHS reaction: Case of Fe+Al binary system, Acta Materialia, 47 (1999) 619-629.

[12] P. NOVÁK, J. KUBÁSEK, J. ŠERÁK, D. VOJTĚCH, A. MICHALCOVÁ, Mechanism and kinetics of the intermediary phase formation in $\mathrm{Ti}-\mathrm{Al}$ and $\mathrm{Ti}-\mathrm{Al}-\mathrm{Si}$ systems during reactive sintering, International Journal of Materials Research, 100 (2009) 3. 